Article

\title{
Ritualization of Affection and Respect: Two Principles of Confucian Ritual
}

\author{
Jaesang Jung \\ Department of Oriental Science, Wonkwang Digital University, Seoul 07448, Korea; jung.jaesang@gmail.com
}

Received: 14 February 2019; Accepted: 21 March 2019; Published: 26 March 2019

\begin{abstract}
Confucian rituals have constituted the foundation of religious practice in the traditional societies of East Asia. Paying attention to the Confucian ritual, this article explores the way Confucianism constructs its symbolic system based on people's natural feelings, particularly in the case of three-year mourning. It intends to show how the two feelings of "affection for the family" (chinchin/qinqin, 親親) and "respect for the honorable" (chonjon/zunzun, 尊尊) are ritualized in Confucian rites, and to illuminate the religious and social dimensions of Confucianism in premodern Korea by analyzing a seventeenth-century controversy over royal mourning from the perspective of these two principles.
\end{abstract}

Keywords: religiousness of confucianism; korean confucianism; affection (chinchin/qinqin); respect (chonjon/zunzun); three-year mourning; controversy on mourning attire; Chosŏn Dynasty; Song Siyŏl; Hŏ Mok; Yun Hyu

\section{Introduction}

Confucianism has played a central role in establishing the foundation of East Asian civilization, covering not only China but also neighboring regions, such as Korea, Japan, Vietnam, and the Ryukyu Kingdom (Okinawa), functioning as the dominant norm in various fields, including philosophy, ethics, law, politics, and religion. The starting point, or the basis, of social norms of Confucianism is natural human feelings. Emotions such as joy, anger, grief, and delight are regarded as natural tendencies, which should be positively expressed and at the same time properly controlled. The Confucian ritual is a way of guiding and cultivating those human feelings, through which Confucianism pursues the realization of the ideal man, society, and state.

There might be various ways of approaching the meaning and role of Confucianism in Korea, but here I focus on the ritual aspect, particularly the ritualization of natural feelings. I focus on Confucian ritual and investigate the way it constructs its symbolic system based on people's natural feelings, particularly in the case of the three-year mourning ritual. I delve into how Confucian scholars ritualize the two fundamental feelings of "affection for the family" (chinchin/qinqin, 親親) and "respect for the honorable" (chonjon/zunzun, 尊尊). To present a showcase, I will analyze the controversy over royal mourning in the seventeenth-century Chosŏn dynasty from the perspective of the two competing principles of 'affection' and 'respect', a case that illuminates the religious and social dimension of Confucianism in pre-modern Korea.

\section{Ritualization of Natural Feelings}

Confucianism has played the encompassing role of giving meaning to and regulating everyday life in pre-modern East Asia. Rites of passage especially, which commemorate one's birth, the transition from childhood to adulthood, marriage, and death, have been fundamentally based on Confucian rituals. In this section, I want to overview the general Confucian understanding of the relationship between the Confucian rituals and natural feelings. 
An illustrative example to show that Confucian ritual is designed and based on 'human natural feeling' is the three-year mourning ritual, which is for expressing grief over the death of one's parent. It is a lengthy ritual lasting precisely twenty-five months. During the mourning period, one must retire from official social activities and live ascetically in a hut near the grave, giving offerings to the dead every morning and evening.

Twenty-five months is quite a long time in fact. Considering that the average lifespan in ancient China was much shorter than today, to impose twenty-five months' mourning could be a harsh demand. However, Confucianism emphasizes that this period of mourning and ascetic life are not arbitrarily chosen but rather designed and guided by natural feelings. It seems that there were voices of dissent over this harsh ritual. A disciple of Confucius, Zai Wo 宰我, whose name is Yu 予, objected to it, saying that three years is too long, and one year is enough. At that time, Confucius answered as follows:

The Master said, "If you were, after a year, to eat good rice, and wear embroidered clothes, would you feel at ease?"

"I should," replied Wo.

The Master said, "If you can feel at ease, do it. But a superior man, during the whole period of mourning, does not enjoy pleasant food which he may eat, nor derive pleasure from music which he may hear. He also does not feel at ease, if he is comfortably lodged. Therefore, he does not do what you propose. But now you feel at ease and may do it."

Zai Wo then went out, and the Master said, "This shows Yu's want of virtue. It is not till a child is three years old that it is allowed to leave the arms of its parents. And the three years' mourning is universally observed throughout the empire. Yu must have also received the three years' love from his parents!". (Analects 17.21) (Confucius 1960)

According to Confucius, the three-year mourning is based on the feeling of grief at the death of a parent, when people usually cannot feel at ease even at home, taste delicious food, or delight in wearing good clothes. The mourning rite ritualizes such emotions, and sets the period as the time for natural recovery from the shock of a family member's death. But the psychological state and the duration of grief can be different from person to person. On this matter, the problem of the extent that the ritual outlasts the emotion occurs.

Zai Wo suggested that one year is enough for mourning a deceased parent. One year means a cycle of four seasons, following which political, economic, and religious ceremonies were held in the agricultural society of ancient China. A year represents a completed time unit unfolding the birth, growth, decline, and death of life. Zai's opinion was probably based on this concept of time. Although Confucius answered Zai, "if you can feel at ease, do it," he was being sarcastic and critical toward Zai's opinion. Given that he maintained the period of mourning following the natural feeling, Confucius might not have had a choice but to answer in such a positive way whatever his intention may have been.

How could the period of mourning be legitimized by a natural feeling? As to the meaning of the mourning ritual, besides the aspect of grief, Confucius also explained it as a return for the parent's love. Every human grows up relying exclusively on their parents' care until the age of twenty-five months - that is what the Chinese count as being three years old and is when one acquires the basic physical and linguistic ability to survive. Grounded in this parent-child relationship in the first phase of human life, Confucius claims that the meaning of the mourning lies in gratitude for one's parents' nursing and caring. It appears that Confucius is explaining its meaning in two distinct ways-grief and gratitude-nevertheless, the two are indivisible if we take into consideration that one's grief for the dead is often intensified with the memory of love. Indeed, Confucius' argument is consistent in that he associates the period of three-year mourning with 'natural feelings.' Confucius claims that one ought to feel what many people do feel. "Feelings" occur naturally. In addition, "what people ought to feel" belongs to a moral dimension because it accompanies a certain amount of learning and 
obligation. There might be continuity and discontinuity between the two. This is the point on which Daoist thinkers criticize Confucianism for its arbitrariness and anti-naturalism. However, Confucian thinkers tried to set up 'natural feeling' by defending the homogeneity or continuity between what one does feel and what one ought to feel, and use this principle as a foundation to conceptualize moral sentiment and construct rituals. ${ }^{1}$

Another important argument legitimatizing the mourning period is found in the thought of Xunzi 荀子， a Confucian of the second century BCE. Just like Confucius, Xunzi agreed that the three-year mourning is based on natural sentiments (qing 情), but he pointed out moreover that some artificial sophistication is imposed on the setting of the mourning period.

Firstly, drawing on the fact that the birds and other animals have their own ways to express their grief over a loss, Xunzi explained that human feeling when faced with the death of one's parents has no limit. The three-year mourning is a ritual to ornament (xiushi 脩飾) the feeling in order to achieve "a good form and a proper order." Since the extent and the duration of grief can vary depending on the person, some will forget their grief in just one day, and some will suffer the pain of loss throughout their life. Even though grief may be the expression of natural feelings, if it is too weak or too intense, it might cause conflicts with other people's feelings and social chaos at the end. To prevent those conflicts and chaos, Xunzi said, "the former kings and sages accordingly established a middle way and fixed a proper measure for it," and made the three-year mourning ritual (Xunzi 2014, pp. 213-14). The function of the mourning ritual is to guide one to express one's feeling of grief in a proper way. It strengthens a feeling that is too weak, such as 'the grief of one day,' and cuts off excessively intense feeling, such as 'lifetime grief.'

Xunzi also made it clear that the period of mourning was artificially fixed. As seen previously, Zai Wo argued that one year is enough to mourn for parents. In the same way, Xunzi also said the standard period of the mourning is one year in principle, according to a cycle of four seasons. Nonetheless, the reason for taking three years is “to add loftiness" (jialong 加隆) (Xunzi 2014, p. 214)2. According to Xunzi, grief can naturally die down in one year, but the mourning period for parents was fixed as more than double that because of an artificial factor, which is that the parents have an 'exalted position (long 隆)' compared to other blood relatives. Xunzi put it, “The lord occupies the most exalted position in the state, and the father occupies the most exalted position in the family. When the most exalted position is held by one person alone, there will be order, but if held by two people, there will be chaos" (Xunzi 2014, pp. 143-44). In human society, both the lord and the father have the 'exalted position and power.' However, those are not naturally endowed but institutionally formulated in comparison to love or grief for family. ${ }^{3}$ The fact that the death of the lord also demands a three-year mourning reveals that there is an artificial factor playing as the principle of the mourning ritual, alongside natural feelings for blood relations.

1 Among the Confucian thinkers, it was Mengzi (孟子, 372-289 BCE) or Mencius who claimed that there is a close relationship between feeling and ritual. Although we cannot find any specific statement about mourning in Mencius, he tried to justify ritual on the basis of natural feelings in a more explicit way by saying that the feeling of reverence (gongiing zhi xin 恭敬 之心) and modesty (cirang zhi xin 辭讓之心) is the beginning of ritual propriety (li zhi duan 禮之端) (Mencius 6A.6; 2A.6) (Mencius 1970).

2 An almost identical statement about the three-year mourning is included in the Liji 禮記 [Record of Rites], in the chapter “Questions about the Mourning for Three Years" (Sannian wen 三年問). See (Liji 1968, p. 393; Liji 2000, juan 58, pp. 1818-19).

3 In Confucianism, the power and privilege of monarch or father were conceived as arbitrary/artificial things, but they are also regarded as natural constraints at the same time. For example, Xunzi suggested a perspective that emphasizes the arbitrariness/artificiality of a ritual and ruling system, but he still used the analogies of a natural model to connect ritual and class system with natural order when he said, "However, just as there is Heaven and Earth, there is a difference between above and below.... As for the fact that two nobles cannot serve each other, and two base men cannot employ each other, this is the Heavenly order of things" (Xunzi 2014, p. 69). Thus, "naturalness" and "artificiality" in this paper are relative terms that are not completely separable. 


\section{The Principles of Affection and Respect}

As seen in the previous section, we can identify in the explanations of Confucius and Xunzi about the period of mourning for three years two factors at work in Confucian rituals, namely 'naturalness' and 'artificiality.' The terms in Confucian texts corresponding to this 'naturalness' and 'artificiality' are, respectively, 'qinqin 親親' (affection) and 'zunzun 尊尊' (respect). These two factors are operative not only in the three-year mourning, but also in deciding other periods of mourning and the types of mourning garments. In this chapter, I will delve into how they are working in particular cases. ${ }^{4}$

First of all, it is worthwhile to review the meaning of the terms. 'Qinqin' literally means "to give affection to those closest" (normally, family), which is working as the principle to decide the period and style of mourning according to the distance or intimacy in kinship. 'Zunzun' literally means "to show respect to those respectable," which decides the period of mourning according to the hierarchical order or social class. In other words, the principle of 'affection' emphasizes natural aspects like kinship or blood relation; that of 'respect' considers artificial aspects such as social status and authority. However, the principle of 'respect' covers not only the relationship between the sovereign and the subject among social status but also the superior and the subordinate inside one's household. ${ }^{5}$ These two principles are sometimes applied alone, and sometimes interwoven to decide the period and style of mourning.

There are six kinds of Confucian mourning periods: three years, one year, nine months, seven months, five months, and three months. The different mourning clothes are divided into five, known as the 'Five Garments' (wufu 五服), which are ranked by the emotional weight of grief: 'unhemmed sackcloth' (zhancui 斬衰), ‘hemmed sackcloth' (zicui 齊衰), 'greater processed cloth' (dagong 大功), 'lesser processed cloth' (xiaogong 小功), and 'fine hemp' (sima 緦麻). Among the five, the 'unhemmed sackcloth' is the heaviest, and the 'fine hemp' is the lightest. 'Heaviness' and 'lightness' here refer to the degree of emotional weight, due to the closeness of blood for the relation.

Literally, 'zhan 斬' means “to cut," and 'cui 衰' designates "humble clothes for mourning." Thus, in the context of the mourning ritual, 'zhancui' designates the unhemmed garment made of rough cut fabric like sackcloth. For example, the death of the closest family member, such as a parent, does not afford a psychological state for hemming the cloth, so the son wears the 'unhemmed sackcloth' to represent the intensity and depth of his grief. The next grade of mourning, 'zicui 齊衰' (hemmed sackcloth) designates 'to hem the edges of sackcloth to be even ( $z i$ 齊),' which implies that the psychological severity of the situation is slighter and it allows one to add hemming. In this way, the mental weights that the mourning clothes represent are symbolized by the degree of artificial processing of fabric, its roughness or fineness, and sewing or hemming.

The six periods and the five styles are combined to provide the diverse patterns of mourning for different occasions: unhemmed sackcloth for three years, hemmed sackcloth for three years, hemmed sackcloth with a staff for a year (zicui zhangji 齊衰杖期), hemmed sackcloth without a staff for a year (zicui bu zhangji 齊衰不杖期), hemmed sackcloth for three months, greater processed cloth for nine months, lesser processed cloth for five months, and fine hemp for three months, etc. The term ' $j i$ 期' means one cycle of the four seasons, or a year. The use of a staff (zhang 杖) has two meanings. Firstly, it designates the chief mourner; secondly, it represents that the mourner's state is such as to be unable to stand up without the staff due to great sorrow. The staff has variants depending on the rank of mourning. In case of the unhemmed sackcloth, a raw bamboo stick is used; the hemmed sackcloth is

4 The Record of Rites or Liji 禮記 specifies six principles to decide the mourning garments in the "Great Treatise” (dazhuan 大傳) chapter. These are: affection (qinqin 親親), respect (zunzun 尊尊), names (ming 名), living in the parental home or outside the home (chulu 出入), age (changyou 長幼), and affinity and external relationship (congfu 從服) (Liji 1968, p. 393; Liji 2000, juan 34, p. 1172). The main and higher principles are the first two, and the rest are subordinate to those two.

5 The two principles of "affection" and "respect" are explained by analogies with mother and father, or water and fire. "The mother is close/affectionate but not revered; the father is revered but not close/affectionate. [It is similar to the relationship of] water and people; water receives affection but not reverence; fire receives reverence but not affection." (Liji 1968, p. 341; Liji 2000, juan 54, p. 1732). 'Fire' implies the relationship of respect which requires that one keep a distance, and on the other hand, 'water' is a good metaphor for the relationship of affection. 
worn with a staff made from the paulownia tree. The closer the kinship and the higher the status of the deceased, the longer the mourning period, and the closer the mourning clothes and accessories are to natural objects, omitting artificial processing.

“Mourning Attire"(Sangfu 喪服) in the Ceremonies and Rites (Yili 儀禮) is an essential manual for the Confucian mourning garments. It describes the periods and the attires I have just mentioned, illustrating the ornaments and objects, as well as their ritual meanings (Yili 2000, juan 28-34, pp. 621-758). In particular, it clarifies what kind of attire and period should be followed, according to the relationship between the deceased and the mourner. Since those explanations are too detailed and specific to discuss in full on this occasion, here I want to focus on the four types of mourning pattern, and summarize the typical cases for wearing these clothes. This will illustrate how the two principles of affection and respect work together in the ritualization of mourning.

(1) The Case of Unhemmed Sackcloth for Three Years (zhancui sannian 斬衰三年)

(1) For one's father

(2) For one's lord

(3) Father wears this for his eldest son

(4) An adopted son of the head of the family wears this for his adoptive father 6

(5) Wife wears this for her husband

(6) A divorced daughter, who returns to her parental home, wears this for her father

(2) The Case of Hemmed Sackcloth for Three Years (zicui sannian 齊衰三年)

(1) If father has passed away, the children wear this for their mother

(2) Mother wears this for her eldest son

(3) The Case of Hemmed Sackcloth with the Staff for a Year (zicui zhangji 齊衰杖期)

(1) If the father is alive, (children wear this) for mother

(2) (Husband wears this) for his wife

(4) The Case of Even Sackcloth without the Staff for a Year (zicui buzhangji 齊衰不杖期)

(1) For one's grandfather and grandmother

(2) For one's other sons [beyond the eldest son]

(3) For one's eldest grandson

(4) An adopted son wears this for his biological parents

(5) A married daughter wears this for her natal parents and for her natal brother who became her natal father's successor

(6) A woman wears this for the lord of her husband

(7) For the parents, wife, eldest son, and grandparents of the lord

(8) A daughter-in-law wears this for her parents-in-law

The preceding examples show how the ranks of mourning are decided by the principles of 'affection' and 'respect.' In cases of mourning for kin, the length and style primarily depend on the principle of 'affection,' which is a natural feeling of bonding among family members. The degree of the feeling makes the material and style of attire different. The period of mourning takes into account the time required for 'natural recovery from the emotional shock' of a family member's death.

6 I follow the interpretation of Lei Cizong 雷次宗 (386-448 CE) on this part, as recorded in the commentary of Jia Gongyan 賈公彦 (fl. 7th ctry. CE) (Jia 2000, juan 29, p. 642). 
The expected recovery time was estimated variously, depending on the closeness of the kin relationship. For example, it was set as three years for one's parents and one year for one's grandparents; the father with a deceased eldest son spends three years in mourning, while the grandfather with a deceased eldest grandson spends a year in mourning. All of these indicate the 'affection,' that is, the intimacy, among kin relations.

The basic rule of mourning for family members is 'affection,' but the principle of 'respect' is also considered. For example, the periods of mourning for parents are all three years, but the kinds of attire differ, so the son wears unhemmed sackcloth for his father and hemmed sackcloth for his mother. It is also noteworthy that the three-year mourning for the mother is only practiced when the father has passed away previously, and otherwise it is shortened to one-year mourning. What is the reason for this? As for 'affection,' the relationship between mother and son is no less intimate than that of father and son. It can be more intimate if pregnancy and childbirth are considered. Nevertheless, if the mourning for one's mother is graded lower, some factor other than 'affection' is decisive. That is consideration of 'respect' for one's father.

In the "Mourning Attire" chapter, it is said that "the father is the most respected [position in the family]" (Yili 2000, juan 11, p. 639). In the patriarchal family model, the 'most respected' position should not be held by two people, but rather only one, and the father is taken as the authoritative figure in the house, just the same as the lord is in the state. In this way of thinking, the mourning for one's mother is downgraded due to the highest status of one's father. In this case, an artificial determination of the 'most respected' position may restrict the son's grief over the loss of his mother. How does the Confucian mourning ritual deal with this problem? If the mother passed away while the father is still alive, the son should take off his mourning attire (hemmed sackcloth with a staff) after a year, but he can maintain xinsang 心喪, 'inner mourning' for his mother for the remainder of the three years. ${ }^{7}$ And the father is allowed to remarry three years after his wife's death, so as to accommodate the son's will to complete the inner mourning (Yili 2000, juan 11, p. 658). All of these situations are resolutions that reconcile one's 'affection' for one's mother with 'respect' for one's father.

Every son wears the unhemmed sackcloth for three years to mourn his father. However, in the case of paternal mourning for one's sons, the mourning attire for the eldest son differs from the other sons. For the eldest son, the father wears the unhemmed sackcloth for three years; for the other sons, he wears the hemmed sackcloth without the staff for one year. In these cases, another factor is also intervening. The only reason for wearing the unhemmed sackcloth for the eldest son is respect for the heir to the household. The "Mourning Attire" chapter explains, "[This is because the eldest son is] the legitimate body connected with the ancestors, and he will convey the weight [of responsibility of the heir]" (Jia 2000, p. 640). This principle of inheritance, the so-called patriarchal family system (zongfa 宗法) has great importance in Confucianism, which aims to prevent disputes over inheritance by imposing consistent principles on the succession of heirs, and ensures a unified kinship order. Unlike for the other sons, the three-year mourning for the eldest son indicates that he inherits a particular authority. In other words, the mourning ritual is a kind of declaration that the principle of inheritance is inviolable and carried through even after the death of the prospective inheritor.

There may be cases where the head of a family is not able to produce a son and adopts one from a brother or a paternal relative in order to continue the family. If so, what kind of mourning should the adopted son undertake, when his adoptive father or his biological father die? For the adoptive father, he should wear the unhemmed sackcloth for three years; for his birth father, the hemmed sackcloth without the staff for a year. In this case, the mourning ritual is not characterized by the 'affection' but by the 'respect' derived from the position of the heir of the household. Because the father is the

7 In 674, the Empress Wu Zetian 武則天 (624-705) proclaimed three-year wearing of the hemmed sackcloth for one's mother, regardless of whether one's father had died. After several disputes, it became a regulation in the Kaiyuan Ritual Manual of The Great Tang (Da-Tang kaiyuan li 大唐開元禮), published in 732 (Jiutangshu 1975, vol. 27, pp. 1023-31). After the Tang, it was common to wear the hemmed sackcloth in three-year mourning for one's mother. See (Nishikawa 2012). 
highest and there cannot officially be two fathers, the adopted son is not allowed to undertake the three-year mourning for his original father, but rather he needs to adjust his feeling of 'affection' in a downgraded form.

When a daughter gets married and leaves her parental home, another artificial rearrangement of the familial hierarchy can be found as in the case of the adopted son. A married daughter wears the one-year morning of hemmed sackcloth for her natal parents. If she gets divorced and returns to her parental home, she wears the unhemmed sackcloth for three years for her father. Marriage is purely an artificial relationship, however, in which the husband is set in the higher status and the wife in the lower. In contrast to the wife wearing the unhemmed sackcloth for three years for her husband, a husband wears the hemmed sackcloth for his wife, according to the principle of the 'respect' due to the patriarch.

For the lord, one must wear the unhemmed sackcloth for three years. It is the same as the case of mourning one's father. However, unlike how the latter occurs due to a blood relationship, the former is based on the political and hierarchical relationship, governed by the principle of 'respect.' Although a wife has no direct relationship with the lord, she wears a mourning garment following her husband. In this case, she wears the garment of the next lower level (i.e., the hemmed sackcloth), in order to express her respect for the husband.

\section{The Controversy over Mourning Attire in Seventeenth-Century Chosŏn}

A particular controversy over mourning attire is one of the representative debates in the history of Chosŏn thought. Modern scholars often refer to it as the yesong 禮訟 or 'Dispute on Ritual.' The dispute was about more than just theoretical differences and it expanded into a political conflict. In this regard, most studies have analyzed the dispute in the context of the political history of 'factional competition' (tangjaeng 黨爭). The main contention of such studies is that the discrepancy in opinions of the seventeenth-century scholars about mourning was due to the schools and factions to which they belonged. Of course, it is noteworthy that those who participated in the dispute each belonged to some faction and had some political stance. But even so, it is too simplistic and schematizing to characterize the controversy as only the conflict of factions. ${ }^{8}$ In this section, I want to approach the controversy from a liturgical perspective concerned with the principles of 'affection' and 'respect.'

As seen in the previous section, the mourning attire for the one who has blood ties to the deceased is basically determined according to the principle of 'affection,' and on top of that, the length of the mourning period and the kind of attire are adjusted by considering the aspect of 'respect.' On the other hand, when it comes to the lord-servant relationship, the principle of 'respect' is dominant. That being so, in the case of those who have a kinship with the lord, which principle should they follow in mourning for the lord? The royal family occupies a unique position that differentiates them from an ordinary household in that the family relationship overlaps with the lord-servant relationship. In short, the problem of whether the lord's kin should wear mourning attire according to their family relations or their socio-political relation to the lord can occur. This was the core issue underlying the seventeenth-century Chosŏn controversy over the mourning ritual.

In 1659, the seventeenth King of Chosŏn dynasty, Hyojong 孝宗 (r. 1649-1659) died. He was the second son of the sixteenth King, Injo 仁祖 (r. 1623-1649). His death brought on a heated dispute over the length and style of mourning to be undertaken by Hyojong's stepmother, the Dowager Queen Cho (Cho-taebi 趙大妃). It was concerned with how the mother should represent her family relationship to her stepson liturgically as well as her hierarchical relationship to the lord. The scholar-officers' various

8 Since the late 1990s, several studies appeared that pointed out the limitations of previous studies centered on the history of politics and clarified the philosophical and ritual meaning of the controversy. These new studies paid attention to the concepts of 'affection' and 'respect' and discussed it from the perspective of Confucian Studies of Classics (jingxue 經學) (Lee 1996a, 1996b; Chang 1998; Rhee 2014). These approaches provide an important perspective on understanding the cultural implications of Confucianism in Chosŏn period. 
proposals for her mourning attire can be summarized by three positions: she should wear the hemmed sackcloth for one year, she should wear the hemmed sackcloth for three years, and she should wear the unhemmed sackcloth for three years. The arguments for each claim are as follows.

Firstly, Song Siyŏl 宋時烈 (1607-1689), the leader of the 'Westerners' (Sŏin 西人), who succeeded the Yulgok 栗谷 school, suggested that the Dowager Queen Cho wear the hemmed sackcloth for one year. Song argued that it is proper for her to wear the "kibok/jifu 期服," i.e., the one-year mourning attire, because Hyojong was the second son and not the first-born son. In the case of a first-born son's death, his mother should wear the three-year mourning attire, just as what "the father wears for the eldest son" as prescribed in the Ceremonies and Rites. On the other hand, in the case of a second son, like Hyojong, the one-year mourning attire (the hemmed sackcloth without a staff) must be applied following the prescription for how to mourn "for the other sons [beyond the eldest son]." Before Hyojong succeeded to the throne, Injo's firstborn son, the Crown Prince Sohyŏn 昭顯 (1612-1645) had died earlier. Injo had worn the three-year hemmed sackcloth attire for him. Since the eldest and first-born son had already mourned for three years with hemmed sackcloth attire, Song believed that the Dowager Queen should wear the mourning attire appropriate for the second son, not for the eldest son (Song 1993, pp. 112, 473-76).

In the case where a father had already mourned for his first-born and eldest son by wearing the unhemmed sackcloth, if he were to wear it again for the next eldest son who became the new heir and thus treat him the same as the firstborn son, Song believes, it would offend against the principle of “not wearing the unhemmed sackcloth twice (buricham/bu er zhan 不蔶斬)" (Yili 2000, vol. 30, p. 668). In addition, if a father were to undertake the three-year mourning for every heir-such as in the case of consecutive deaths of many sons-and names each next-eldest son as 'the eldest son' (changja/zhangzi 長子) one after another, Song argued, it would not only confuse 'the legitimate line of descendants' (chŏkt'ong/ditong 嫡統), but also lead to excessive use of the unhemmed sackcloth. Therefore, he claimed that only the legitimate first-born son is eligible to be mourned with the unhemmed sackcloth; any other son merits only mourning with the one-year hemmed sackcloth, even if he is the successor to the throne (Song 1993, pp. 108, 207). In sum, Song's claim was based on a general perspective that did not distinguish between King's family and ordinary families. Eventually, it was criticized in that it failed to takes the peculiarity of the royal family into consideration.

Secondly, the suggestion that the Dowager Queen should wear the hemmed sackcloth for three years was maintained by Hŏ Mok 許穆 (1596-1682), who belonged to the 'Southerner' (Namin 南人) faction that succeeded the Toegye 退溪 school. Hŏ argued against Song as follows: although Hyojong was the second son, because he had ascended the throne and continued the royal line, he should be regarded as 'the eldest son.' Therefore, the King's mother should wear the hemmed sackcloth for three years for him. Specifically rejecting Song's concepts of "the legitimate son" and "the eldest son," Hŏ argued that 'the legitimate son' (chŏkcha/dizi 嫡子) designates every son of one's legal first wife (chŏkch'ó/diqi 嫡妻). According to his interpretation, every son of the first wife can become 'the eldest son,' on the ground of Jia Gongyan's commentary, which states, "If the first son is dead, the second eldest son born of one's legal wife is chosen to be established [as the heir] and called 'the eldest son (changja/zhangzi 長子)'”' (Jia 2000, p. 640). Thus, his conclusion is that since Hyojong was the legitimate second son who succeeded the heir, the Dowager Queen Cho must wear the hemmed sackcloth for three years, on the grounds that is what "the mother wears for the eldest son" according to the "Mourning Attire" chapter (Hŏ 1992, pp. 456-57).

Hŏ also reputed the principle of "not wearing the unhemmed sackcloth twice" on which Song's argument was based. According to Hŏ, that regulation corresponds to those cases where a married daughter or an adopted son downgrades their mourning for their biological parents from the three-year to the one-year practice, but it does not apply to a case where the father wears the three-year mourning attire for his 'eldest son' who succeeded the heir. The reason for the father's practicing the three-year mourning for his eldest son is to give greater importance to the succession of the heir than to the 
blood ties between father and son. Therefore, it would not be erroneous for the father to undertake the three-year mourning several times (Но̆ 1992, pp. 459-61).

Thirdly, it was Yun Hyu 尹鍴 (1617-1680), who also belonged to the 'Southerners,' who advocated that the Dowager Queen should wear the unhemmed sackcloth for three years. He applied to her case the regulation of what is demanded by the "Mourning Attire" chapter when mourning "for the lord." He backed up his claim by appealing to three Confucian ritual books, the Ceremonies and Rites, the Rites of Zhou (Zhouli 周禮), and the Explanation of the Record of Rites (Liji shu 禮記疏). Firstly, he based his claim on the statement in the "Mourning Attire" chapter of the Ceremonies and Rites as just noted, and secondly, he found evidence concerning mourning for the monarch in the Rites of Zhou, which states that, "generally, the mourning [attire] for the Heavenly King is unhemmed sackcloth" (Zhouli 2000, juan 21, p. 654). Finally, he found support in the commentary of Kong Yingda 孔穎達 (574-648) on the Record of Rites, which reads, "generally, the five kinds of relatives ${ }^{9}$ of a feudal lord wear the unhemmed sackcloth [in mourning for him]. Because the body of a feudal lord should be respected, they cannot wear any lighter attire designated for their original kinship relation [to him]" (Kong 2000, p. 1154).

On the ground of these protocols, Yun maintained that "wherever the heir to the throne is, that is certainly where the legitimate line belongs" (Yun 1994, pp. 398-402; Yun 1974, pp. 1045-51). This was a criticism against Song's approach that differentiates the first-born son from the second, even when the latter is the King who succeeded to the throne. At the same time, this remark also targeted Hŏ, who thought that the three-year mourning is not permitted for the sons of concubines, even when one of them was the heir to the household, for they are not 'legitimate sons.' ${ }^{10}$ Yun claimed that even in the case where a son of a concubine became King, his relatives should wear the three-year attire in mourning. Yun's stance makes clear that royal rituals cannot be the same as the rituals of ordinary families. In other words, if the principle of 'affection' is foremost in the ritual of ordinary families, the principle of 'respect' is predominant in the rituals of the royal family, where succession to the throne is most important.

These are the main points of the three scholars' claims. Each claim can be illuminated further when viewed from the perspective of 'affection' and 'respect.' Song's argument that the Dowager Queen should wear the one-year mourning attire for Hyojong considers only whether or not Hyojong is the first-born son. It disregards his being the successor of the royal family. Of course, the fact that Song placed great emphasis on 'the first-born son' is because he attached importance to succession in the family. However, his argument has the following problems. In a case where the successor in the family was one of younger sons, if the one-year attire is practiced, then the ritual reveals only that this son was not 'the firstborn son,' but fails to represent his being the successor in the family. As a result, it neglects the principle of 'respect' which emphasizes succession. The standard suggested by Song made no exception for the royal family. Thus, it values only biological relations as determined by the natural birth order and fails to take the political status of the King into account. Indeed, this is a quite sensitive matter that could provoke dispute over the legitimacy of the succession. Song faced criticism and blame that he has downplayed the kingship.

The claims of Hŏ and Yun that the Dowager Queen Cho should wear the three-year mourning attire are intended to highlight the status of the king who succeeded as the heir of the royal family.

9 The five kinds of relatives (wuzhu 五屬) designate the kin relation who wear 'Five Garments' (wufu 五服). The extent to whom the 'Five Garments' are applied covers vertically from the paternal great-great-grandfather (gaozu 高祖) down to the great-great-grandson (xuansun 玄孫), and horizontally includes the collateral families as well as those of the direct line.

10 As seen in the previous section of this paper, the "Mourning Attire" chapter explains the reason that father wears the unhemmed sackcloth for three years in mourning for the eldest son by saying that "[the eldest son is] the legitimate body connected with the ancestors, and he will convey the weight [of responsibility of the heir]." Song thought that the "legitimate body (chŏngche/zhengti 正體)" designates literally the legitimate son born of the first wife, and in case of a younger son (次子), he is not eligible to be mourned with the unhemed sackcloth despite his succeeding as heir. Hŏ thought that every son of the first wife is the "legitimate body," but denied that status to the sons of concubines, who have "the body [connected to ancestors] but illegitimate." Yun admitted the differentiation between the eldest and the younger sons, the legitimate and the illegitimate sons, but he argued that in the case where one of them succeeded as heir and became King, his status goes beyond the standard of mourning for 'the legitimate body' and instead the attire for mourning him should be the three-year unhemmed sackcloth, as is demanded for "the most respected (chijon/zhizun 至尊)." 
However, the difference between Hŏ and Yun should be noted. Hŏ argued that the Dowager Queen Cho should wear the hemmed sackcloth, which is supposed to be worn by the mother when mourning for the eldest son who was the heir. Through such a ritual, Hŏ aimed to highlight the status of the King as based primarily on the ground of blood relationships. However, his suggestion was also based on a general perspective that did not distinguish between an ordinary family and the royal family. Although Hŏ criticized Song for failing to display Hyojong's position as a sovereign, he was likewise unable to offer any approach that considered the particularity of the royal family. This is evident in what he said about the mourning for an illegitimate son, namely: "If an illegitimate son is established as the successor [of a family], he is referred to as the body [connected to ancestors] but illegitimate, and not eligible to be mourned for three years. This is because he is the son of a concubine" (Но̆ 1992, p. 457). Eventually, this view arrives at the same conclusion, even in the case of the monarch who is the son of a concubine but succeeds to the throne.

Yun has a firm stance that no matter who succeeds to the throne, regardless of whether he is the eldest or a younger son, a legitimate or an illegitimate son, all his relatives should wear the unhemmed sackcloth for three years, just like every servant of the monarch, so as to show respect for the King, the most exalted station. His viewpoint was that the mourning of the royal family should not be the same as that of ordinary families. While Hŏ's view adds the principle of 'respect' to the base of 'affection,' Yun's view was based on the principle of 'respect' from the beginning and absolutized the position of the monarch.

However, a problem with Yun's argument is that the "Mourning Attire" chapter has no prescription for the mourning of the royal family. That chapter of the Ceremonies and Rites, as a matter of fact, provided rituals for the learned class (shi \pm ), and not for the monarch. Because of that, Yun drew his evidence related to mourning for the king from the Rites of Zhou. Nevertheless, Yun's claim still has a problem. If the Dowager Queen wears the unhemmed sackcloth only in virtue of her hierarchical relationship to the King, the lord-servant relationship is emphasized in the ritual more than the mother-son relationship, resulting in treating his mother like his servant. Because of this, Yun's theory provoked enormous antipathy and suffered severe criticism, being blamed as 'a theory that regards [the King's] mother as a servant' (sinmo-sŏl 臣母説). The cause of the resentment is rooted in the Confucian ethic in which even the King must lower his head in front of his mother and fulfill his duty of filial piety, an unbreakable norm. Notably, Song attacked Yun's thought as anti-Confucian. Portraying himself as a defender of Confucianism, he accused Yun of being a heretic in his interpretation of Classics. In this way, the controversy over the mourning ritual became overheated and expanded as a political struggle, involving many schools and factions.

The conflict among schools or political interests might underlie the seventeenth-century controversy on mourning attire. However, we should not overlook what made the struggle so bitter and fierce was that the mourning ritual is directly linked to the core values of Confucianism, as well as the problem of legitimacy of political power. In terms of schools or factions, Song belonged to the 'Westerners' who succeeded the Yulgok school, while Hŏ and Yun belonged to the 'Southerners' who succeeded the Toegye school. As the former defended the one-year mourning attire, and the latter defended the three-year mourning attire, the controversy may seem to be a battle between the two academic groups on the surface. However, as we have seen above, in terms of the principles of 'affection' and 'respect,' Song and Hŏ adopted the same stance that prioritizes the principle of 'affection' to the blood relationship; on the contrary, Yun belonged to a different group that gives priority to the principle of 'respect' for the political position of the monarch.

All three claims have scriptural bases, including the authoritative exegeses of the Confucian ritual books of ancient China, which were considered as canonical scriptures. Although those liturgical texts give information about the principles of 'affection' and 'respect,' the texts themselves permit various and even contradictory interpretations, due to their imperfections, inconsistencies, or contradictions. If one tries to practice the mourning ritual in situations for which those scriptures give no clear and unambiguous prescription, it is unavoidable to either prioritize or harmonize those two principles. 


\section{Concluding Remarks}

Confucianism articulated a way to live and the value of living in accordance with human nature, aiming to realize such a life through practicing $l i$ 禮, that is 'ritual' or 'propriety,' in every behavior. The mourning ritual was designed to allow the living to properly express sadness and grief for the dead. As we have seen above, the period of the mourning and the type of attire were determined by the two principles of 'affection' and 'respect,' and the mourning ritual played a role in maintaining the primogenital order by ritualizing the practice of 'affection among blood relationship' and 'respect for the eldest and the lord.' The primogenital order has been the basis of the traditional Chinese family, society, and state system, and the ritual of mourning has been particularly emphasized among the various rituals of Confucianism.

The Chosŏn Dynasty was founded on the national ideology of Neo-Confucianism, called the "Studies of Nature and Principle (Sŏngnihak 性理學)." Chosŏn can be called a liturgical state in the sense that all institutional systems were designed with great concern that Confucian ethics and moral sentiments should be emphasized and realized through various ritual codes. Through careful exploration of the controversy over mourning attire in seventeenth-century Chosŏn, we can see that all debaters were trying to find a ritual which they could best manifest 'affection' and 'respect.' For them, the crucial question was how to embody both principles in the rituals for the royal family, where the family relationship and the lord-servant relationship overlapped each other.

It is especially noteworthy that many scholars of Chosŏn at that time denounced Yun's opinion for treating the King's mother as his servant. Although Yun had no such intention and his evidence was all drawn from the Confucian Classics, he was blamed for denying or ignoring the feeling of affection between mother and son and the required filial piety toward one's mother. For most Confucian scholars, those sentiments had absolute priority over the respect that the mother of the King should show to her son.

The following is another example of prioritizing the relationship of 'affection' between parents and children over that of 'respect' between the lord and the servant: when a parent of a bureaucrat died, the bureaucrat should resign from the post and return to his hometown for the three-year mourning ritual. If we take such an atmosphere during the Chosŏn period into account, we can understand why the reaction against Yun was not just an academic criticism but also an emotional rejection. Emotion and the value of affection were regarded as the basis of humanity and morality, and this kind of ethos appears throughout the history of Confucianism, and in the case of the Chosŏn Dynasty, it had been internalized even more intensely through rituals.

The existence of a vast amount of studies and commentaries on the Family Rituals of Master Zhu (Zhuzi jiali 朱子家禮) ${ }^{11}$ shows how much Chosŏn Confucians endeavored to ritualize everyday life. ${ }^{12}$ Future study should give further consideration to the ritualization of human feeling in Confucianism. It will lead to a new understanding of its influence on East Asian culture.

Funding: This research was supported by the Wonkwang Digital University for Academic Research Grant (2018).

Acknowledgments: I want to thank Eric Hutton for offering precious comments and helpful corrections and suggestions. This paper also has been much improved from the feedback of anonymous reviewers and Sungho Lee.

11 The Family Rituals of Master Zhu was written by the famous Confucian Zhu Xi (朱喜, 1130-1200) in the Southern Song dynasty. It is also called the Family Rituals of Wen Gong (文公家禮). It was indispensable for family rituals not only in China but also in Chosón, and consists of manuals for the capping ritual (guanli 冠禮), wedding ritual (hunli 婚禮), mourning ritual (sangli 皮禮), and sacrificial ritual [for ancestors] (jili 祭禮). An English translation is available: see (Ebrey 1991).

12 More than 450 kinds of commentaries, studies, and manuals concerning the Family Rituals of Master Zhu were published during the Chosón from the sixteenth to the early twentieth century. Such a large volume of publications indicates that, beyond academic interest, detailed manuals were in high demand for practicing family rituals in everyday life. It shows a particular characteristic of Chosŏn Confucianism, in comparison with that of the contemporary Ming-Qing dynasties. For a complete list of commentaries and studies of the Family Rituals of Master Zhu published in the Choson period, see (Chang 2013a, 2013b). 
Conflicts of Interest: The author declares no conflict of interest.

\section{References}

Chang, Dongwoo. 1998. A Study on Ta-San (茶山)'s Lihsueh (禮學): Laying Stress on the Comparative Study of Ili 儀禮 “Sangfu 喪服” and Sanglyesachon 喪禮四箋 “Sanggipyol 喪期別”. Ph.D. thesis, Yonsei University, Seoul, Korea. (In Korean)

Chang, Dongwoo. 2013a. Studies of the Family Rituals of Master Zhu in the Chosŏn Period. Translated by Byeon Yeong-ho, Jung Jae-sang. The Tsuru University Review 78: 45-68. (In Japanese)

Chang, Dongwoo. 2013b. Studies of the Family Rituals of Master Zhu in the Chosŏn Period. Tae-dong Yearly Review of Classics 31: 209-55. (In Korean)

Confucius. 1960. Confucian Analects, The Chinese Classics. Translated by James Legge. Hong Kong: Hong Kong University Press, vol. 1.

Ebrey, Patricia Buckley. 1991. Chu Hsi's "Family Rituals": A Twelfth-Century Chinese Manual for the Performance of Cappings, Weddings, Funerals, and Ancestral Rites. Princeton: Princeton University Press.

Hŏ, Mok. 1992. Kiōn 記言 [Record of Sayings]. Edited by Minjok Munhwa Chujin Wiwŏnhŏe. HMC Han'guk Munjip Ch'onggan [Korean Literary Collections in Classical Chinese]. Seoul: Kyŏngin Munhwasa, vol. 98.

Jia, Gongyan. 2000. Yili Yishu 儀禮義疏 [Explanation on Meanings of the Ceremonies and Rites]. In Shisanjing zhushu 十三經注疏 [Commentaries and Explanations on the Thirteen Classics]. Edited by Shisanjing zhushu zhengli weiyuanhui 十三經注疏整理委員會. Beijing: Beijingdaxue Chubanshe.

Jiutangshu 舊唐書 [Old Book of Tang]. 1975. Beijing: Zhonghua shuju.

Kong, Yingda. 2000. Liji Zhengyi 禮記正義 [Orthodox Meaning of the Book of Rites]. In Shisanjing zhushu十三經注疏 [Commentaries and Explanations on the Thirteen Classics]. Edited by Shisanjing zhushu zhengli weiyuanhui 十 三經注疏整理委員會. Beijing: Beijingdaxue Chubanshe.

Lee, Bongkyoo. 1996a. Rethinking of Philosophical Analysis on the Dispute on Ritual 禮訟의 哲學的 分析에 대한 再檢討. Daedong Munhwa Yeongu 31: 151-77. (In Korean)

Lee, Bongkyoo. 1996b. Philosophical Analysis of Chŏng Yak-yong on the Dispute on Ritual in the 17th Century 17세기 예송 (禮訟) 에 대한 정약용의 철학적 분석. Gongja Hak 2: 223-53. (In Korean)

Liji 禮記 [Record of Rites]. 1968. In Sacred Books of the East. Translated by James Legge. Delhi: Motial Banarsidass, vol. 28.

Liji 禮記 [Record of Rites]. 2000. In Shisanjing Zhushu 十三經注疏 [Commentaries and Explanations on the Thirteen Classics]. Edited by Shisanjing zhushu zhengli weiyuanhui 十三經注疏整理委員會. Beijing: Beijingdaxue Chubanshe.

Mencius. 1970. Mencius. Translated by Din Cheuk Lau. London: Penguin Books.

Nishikawa, Yukihiro. 2012. The Empress Wu Zetian and the Grace of Mother 則天武后と母の恩. Chugoku Kenkyu Shukan 中國研究集刊 [Bulletin of Chinese Studies] 54: 16-35. (In Japanese)

Rhee, Won-taek. 2014. The Controversy about the Confucian Funerary Rituals in the 17th C. Choson Dynasty. The Tsuru University Review 79: 163-76. (In Japanese)

Song, Siyŏl. 1993. Songja Taejŏn 宋子大全 [The Completed Works of Master Song]. HMC. Seoul: Kyŏngin Munhwasa, vols. 108-16.

Xunzi. 2014. Xunzi: The Complete Text. Translated by Eric L. Hutton. Princeton: Princeton University Press.

Yili 儀禮 [Ceremonies and Rites]. 2000. In Shisanjing zhushu 十三經注疏 [Commentaries and Explanations on the Thirteen Classics]. Edited by Shisanjing zhushu zhengli weiyuanhui 十三經注疏整理委員會. Beijing: Beijingdaxue Chubanshe.

Yun, Hyu. 1974. Paekho ChŏnSŏ 白湖全書 [The Completed Works of Paekho]. Daegu: Kyungpook University Press, vol. 2.

Yun, Hyu. 1994. Paekho Sŏnsaeng Munjip 白湖先生文集 [The Collected Works of Master Paekho]. HMC. Seoul: Kyŏngin Munhwasa, vol. 123.

Zhouli 周禮 [Rites of Zhou]. 2000. In Shisanjing zhushu 十三經注疏 [Commentaries and Explanations on the Thirteen Classics]. Edited by Shisanjing zhushu zhengli weiyuanhui 十三經注疏整理委員會. Beijing: Beijingdaxue Chubanshe.

(C) 2019 by the author. Licensee MDPI, Basel, Switzerland. This article is an open access article distributed under the terms and conditions of the Creative Commons Attribution (CC BY) license (http:/ / creativecommons.org/licenses/by/4.0/). 